\title{
The Effect of Covid-19 on the Presentation and Management of Head and Neck Infections of Dental Origin
}

\section{Original Article}

\author{
Yasser Nabil
}

Department of Oral and Maxillofacial Surgery, Faculty of Oral and Dental Surgery,
Misr University for Science and Technology, Cairo, Egypt

\begin{abstract}
Purpose: The Egyptian authorities announced a period of national partial lockdown on $25^{\text {th }}$ March 2020 to reduce disease burden on the Ministry of Health Hospital Service, the lockdown was eased by the end of June, reopening different facilities, and places of worship, with some restrictions in place to limit crowding. This study aimed to determine the effect of Sars, Cov2, during the partial lockdown on the presentation, and management of maxillofacial infections during the pandemic.

Materials and Methods: This study retrospectively analyzed all patients admitted to Oral and Maxillofacial Surgery Department from $25^{\text {th }}$ of March 2020 to $25^{\text {th }}$ of June 2020 and compared with other admitted cases over the same period in the two preceding years.

Results: The results of the study suggest that there has been an overall decrease in the number patients admitted with head and neck infections of dental origin. The severity of infection was much higher. Patients required more invasive treatment through extraoral incisions. Local anesthesia was the prevalent method as it decreases the risk of virus transmission to more theater personals and maxillofacial surgeons.

Conclusion: The performance of incision and drainage under local anesthesia limits the need for anesthetic equipment and drugs. No change was found regarding the length of hospital stay with a mean of 3 days, this is considered adequate for the patient management. Larger sample of patients and longer multicenter studies are needed to determine the impact of the novel virus on head and neck infection of dental origin.
\end{abstract}

Key Words: COVID-19, dental facial infection, head and neck infection, lockdown, maxillofacial infection

Received: 20 October 2020, Accepted:

Corresponding Author: Yasser Nabil, Department of Oral and Maxillofacial Surgery, Faculty of Oral and Dental Surgery, Misr University for Science and Technology, Cairo, Egypt, Tel.: 01001451772, E-mail: dryasser_nabil@yahoo.co.uk

ISSN: 2090-097X, January 2021, Vol. 12, No. 1

\section{INTRODUCTION}

The World health organization (WHO) declared that, the novel coronavirus was first was first encountered in Wuhan, Hubei Province, China, in December 2019 when patients started to present with community acquired severe respiratory distress and pneumonia, it named the disease as (COVID-19).1 As a result of the delay of travel restrictions, the virus was rapidly disseminated to most countries in the world, and has caused more thousands of deaths globally ${ }^{[2]}$.

The WHO waited till last days of January 2020 and declared the COVID-19 outbreak a "Public Health Emergency of International Concern", when the number of infected individuals reached 130,00 in more than 100 countries in all continents they classified it as pandemic ${ }^{[3]}$. The Chinese Center for Disease Control and Prevention announced the identification of severe acute respiratory syndrome coronavirus (SARSCoV-2), a single stranded RNA virus, as the causative pathogen of
COVID-19. The pandemic of the virus started within few days and reached almost all continents ${ }^{[4]}$.

The Severe Acute Respiratory Syndrome (SARS) epidemic of 2003, having a major difference than COVID-19 in that the former was considerably more dangerous with a cumulative fatality rate (CFR) of $11 \%$ compared to an estimated CFR for COVID-19 of $<1 \%{ }^{[5,6]}$. The virus was confirmed to have reached Egypt on $14^{\text {th }}$ of February ${ }^{[7]}$. Egypt's health ministry announced the first case in the country at Cairo International Airport involving a Chinese national on $14^{\text {th }}$ February. The Egyptian government scaled up preventive measures, with a partial national lockdown starting on $25^{\text {th }}$ March to ease the burden on the Ministry of Health hospital Service. These measurements include restricting the movement between cities, and limiting the opening hours of public services, the lockdown was eased by the end of June; reopening different facilities, and places of worship, with some restrictions in public places to limit crowding, social distance measurement was established ${ }^{[8]}$. 
The asymptomatic incubation period for patients with COVID-19 has been reported to be from one day to 14 days $^{[9]}$. The novel virus has a specific route of transmission, patients release large amounts of infectious viral particles in the form of droplets from coughing, sneezing and respiratory secretions. This mode of transmission by droplets puts the healthcare professionals at an increased risk of infection, especially from asymptomatic patients $^{[10]}$.

Although the virus is not considered as an airborne infection, the viral particles if aerosolized, tend to remain for protracted periods of time in the environment, most oral and maxillofacial surgery and dental procedures change the splashes of the virus in the saliva and change it to more dangerous aerosol type.

Several health authorities had released recommendations postponing all nonurgent elective procedures. In addition, dental, aerosol generating procedures (AGPs) were only permitted in urgent or emergent settings with proper PPE, as emerging data demonstrated the high risk of viral transmission via respiratory droplets ${ }^{[11,12]}$

\section{Aims and objectives:}

We aim to determine the effect of SARSCoV-2 on infection of dental origin, during the $24^{\text {th }}$ week of partial lockdown in 2020; that affects the presentation, and management of maxillofacial infections during the pandemic.

\section{PATIENTS AND METHODS}

A retrospective analysis of patients admitted to the Oral and Maxillofacial Surgery Department of the Specialized Dental Teaching Hospital and the Oral and Maxillofacial Surgery Department of Misr University of Science and Technology during the period in which the Egyptian Authorities announced a period of national partial lockdown on $25^{\text {th }}$ March 2020 to $25^{\text {th }}$ June 2020 as a result of Corona virus pandemic; we compared those data with the ones of the previous 2 years.

The data analyzed included patient demographics, location of infection, severity of the case, offending tooth, type of antibiotic administrated and its route of delivery, surgical management and approach, anesthetic technique, length of patient's hospital stay.

\section{RESULTS}

One hundred and fourteen patients were admitted to the Oral and Maxillofacial Surgery Department at the Specialized Dental Teaching Hospital and Maxillofacial Surgery Department at Misr University of Science and Technology during the period in which the Egyptian authorities announced a period of national partial lockdown on $25^{\text {th }}$ March 2020 to $25^{\text {th }}$ of June 2020 to reduce disease burden on the Ministry of Health Hospital Service. During the $24^{\text {th }}$ week of partial lockdown in 2020, 114 maxillofacial patients were received. This represents a 33.3\% reduction from 2019 where 171 patients were admitted to the hospital and a $32.1 \%$ reduction from 2018 where 168 patients were inpatients. The number of patients seen with cervicofacial infection was decreased, in 2020, sixty-seven patients presented with cervicofacial infection, a $32.3 \%$ and $31.6 \%$ reduction from $2018(\mathrm{n}=99)$ and $2019(\mathrm{n}=98)$ respectively.

There was no statistical difference regarding patients age and sex. Patient aged between 9 years and 77 years in the control years, during the lockdown period the aged between 10 to 76 years. There was no statistical difference regarding the patient gender between the control years and the period of lockdown with male to female ratio of $2: 1$. The important finding was that, although the total number of patients admitted due to infection were less than the preceded years, the severity of infection was much higher, $58.2 \%$ had submandibular infection, two cases of Ludwig's angina $2.89 \%$, compared to 2019 the submandibular infection were 53\%, Ludwig's angina represented $1 \%$, in year 2018 submandibular infection represented 55,5\%, Ludwig's angina represented $0 \%$.

In retrospective analysis of the causes of infection were comparable, the most common cause was acute infected carious was lower wisdoms in $45 \%$ of the cases, infected carious lower molars in $25 \%$, followed by acute infected cystic lesions at the lower anterior teeth in $15 \%$, acute infection at the upper canine in $10 \%$, and infected upper cystic lesions in $5 \%$.

The medical condition of the patients was not statistically significant between the period of lockdown and, it revealed insulin dependent diabetics represents $20 \%$ of cases, uncontrolled non-insulin dependent diabetics in $25 \%$ of the patients, patients with ischemic heart conditions figured $15 \%$ of cases, the remaining $40 \%$ were fit and well. 
Reviewing the surgical management, no difference was found between the management in the three years, removal of the cause was the prime goal to achieve, the intraoral incision and the drainage was the preferred technique, the extraoral incision and the drainage was done in similar fashion with slight increase in the period of the lockdown $10 \%(n=7 / 67)$ compared to year the 2019 and 2018 respectively were $9.2 \% \quad(n=9 / 98)$ and $9.1 \% \quad(n=9 / 99)$ of the patients which required extraoral incisions.
Reviewing the medical management, the antibiotic regimen was comparable in the three years, the systemic broad-spectrum antibiotic administered via intra venous route (ampicillin, salbictam combination was the preferred type $1500 \mathrm{mg}$ three times daily, as well as narrow spectrum IV metronidazole $500 \mathrm{~mm}$ drip tid.

Analysis of the results found that there are no different in the length of the hospital stay compared to the preceded years, with average time of three days.

Cervicofacial Infection in year 2018

\begin{tabular}{lcc}
\hline & 2018 \\
\hline Buccal space & 25 & \\
Canine space & 20 & \\
Submandibular space & 55 & 99 \\
Ludwig's angina & 0 & \\
& Total & \\
\hline
\end{tabular}

Cervicofacial Infection in year 2019

\begin{tabular}{lcc}
\hline & 2019 \\
\hline Buccal space & 33 & \\
Canine space & 12 & \\
Submandibular space & 52 & 98 \\
Ludwig's angina & 1 & \\
& Total & \\
\hline
\end{tabular}

Cervicofacial Infection in year 2020

\begin{tabular}{|c|c|c|c|}
\hline \multicolumn{4}{|c|}{2020} \\
\hline Buccal space & & 27 & \\
\hline Canine space & & 10 & \\
\hline Submandibular space & & 39 & \\
\hline Ludwig's angina & & 2 & \\
\hline & Total & & 67 \\
\hline
\end{tabular}




\section{DISCUSSION}

SARSCoV-2 affected all worldwide health care systems, to decrease its burden on the national medical services; many measures have been taken by the health authorities to slow down the rapid spread of the pandemic. Containment of the population has been set up throw lockdown measurements, with the reduction in outpatient visits, the majority of all elective maxillofacial surgeries had been reduced or cancelled. Only urgent or emergency surgeries were not are not postponed. The number of total admissions in our units demonstrated a reduction rate. This represents a 33.3\% reduction from 2019 where 171 patients were admitted to the hospital and a $32.1 \%$ reduction from 2018 where 168 patients were inpatients. The number of patients seen with cervicofacial infection was decreased in similar percentages. The anxiety and the of hospital acquired contagion have led to the obvious reduction in the patients' number seeking hospital advice. In the three years analyzed, the most common cause of admission due to infection was related to infected lower molars. None of them was due to postsurgical extraction complication of impacted wisdoms, obviously this elective surgical procedure was postponed during the time of lockdown. The important finding was that although the total number of patients admitted due to infection was less than that in the preceded years, the severity of infection was much higher as 58.2\% had submandibular infection, two cases of Ludwig's angina $2.89 \%$, compared to 2019 , the submandibular infection were 53\%, Ludwig's angina represented $1 \%$ in year 2018 submandibular infection represented 55,5\%, Ludwig's angina represented $0 \%$. Our results comes in agreement with other articles that showed increase of the severity of infection during Covid-19 lockdown period ${ }^{[13,14]}$.

The surgical management of patients admitted also almost no difference in the three years, except the slight increase in patients showed requiring extraoral incision and drainage, this related to the more extinctive form of infection they had .The trend of management is to perform incision and drainage under local anesthesia, that helped in decreasing the risk of potential risk of transmission of SARSCoV-2 from patients during General anesthesia specially during intubation and extubating techniques. The use of local anesthesia decreases the risk of virus transmission to more theater personals, and maxillofacial surgeons. The performance of incision and drainage under local anesthesia is cost effective, it reduces the need for anesthetic equipment and drugs.

\section{CONCLUSION}

The aim of this article is to review the effect of SarsCov2 during the $24^{\text {th }}$ week of partial lockdown in 2020 on the presentation, and management of maxillofacial infections. There has been an overall decrease in the number patients admitted with maxillofacial infection of dental origin. The severity of infection was much higher. Patients presenting during lockdown required more invasive treatment modalities e.g. through extraoral incisions. The use of local anesthesia is recommended, as it decreases the risk of virus transmission to more theater personals, and maxillofacial surgeons. The performance of incision and drainage under local anesthesia limits the need for anesthetic equipment and drugs. We found the length of hospital stay with a mean of 3 days is considered adequate for the patient's management.

Larger sample of patients and longer multicenter studies are needed to determine the impact of the novel virus on maxillofacial infections of dental origin.

\section{CONFLICT OF INTEREST}

There are no conflicts of interests.

\section{REFERENCES}

1. Zhu N, Zhang D, Wang W, et al. A Novel Coronavirus from Patients with Pneumonia in China, 2019. N Engl J Med 2020. Jan 24.

2. World Health Organization. Novel Coronavirus (2019-nCoV) situation report-1. https://www. who.int/docs/default-source/coronaviruse/ Situation reports/20200121-sitrep-1-2019ncov.pdf?sfvrsn=20a99c10 4. (Accessed at 10 February 2020)

3. Mahase E. China coronavirus: WHO declares international emergency as death toll exceeds 200. BMJ. 2020;368:m408.

4. Corman VM, Landt $\mathrm{O}$, Kaiser M, et al. Detection of 2019 novel coronavirus $(2019-\mathrm{nCoV})$ by realtime RT-PCR. Euro Surveill. 2020; 25:2000045

5. Park M, Thwaites $\mathrm{R}$, Openshaw $\mathrm{P}$, et al. COVID-19: Lessons from SARS and MERS. Eur J Immunol 2020; 50:308.

6. Rajgor D, Lee M, Archuleta S, et al. The many estimates oftheCOVID-19 case fatality rate. Lancet Infect Dis 2020.; Vol 20 July ; 776-777

7. Elsevier. "Novel Coronavirus Information Center". Information about COVID-19 | World Health Organization | who.intwww.who. int/covid-19/information Elsevier Connect. Archived from the original on 30 January 2020. Retrieved 15 March 2020. 
8. "Egypt announces first Coronavirus infection". Egypt Today. 14 February 2020. Archived from the original on 15 February 2020. Retrieved 14 February 2020. COVID-19 pandemic in Egypt www.care.gov.eg/

9. Huang C, Wang Y, Li X, et al. Clinical features of patients infected with 2019 novel coronavirus in Wuhan, China. Lancet. 2020;395(10223):497e506. https://doi.org/10.1016/S0140-6736(20)30183-5.

10. Peng $\mathrm{X}, \mathrm{Xu} \mathrm{X}, \mathrm{Li} \mathrm{Y}$, Cheng L, Zhou X, Ren B. Transmission routes of 2019-nCoV and controls in dental practice. Int J Oral Sci. 2020;12(1):9.

11. Ricketts S, Gill HS, Fialkov JA, Matic DB, Antonyshyn OM. Facial fractures. Plast Reconstr Surg. 2016; 137:424e-44e. Centers for Disease Control and Prevention: Coronavirus Disease
2019 (COVID-19) Information for Healthcare Professionals. March 26, 2020. Available at: https:/www.cdc.gov/coronavirus/2019- ncov/ hcp/index.html. Accessed March 27, 2020

12. Meng L, Hua F, Bian Z: Coronavirus disease 2019 (COVID-19): Emerging and future challenges for dental and oral medicine. J Dent Res 99:481, 2020

13. Hammond D, Hughes F, Stirrup P, Barkworth N.Setting up and maximising the usage of an Urgent Dental Care Centre in Blackpool. Sharing our experiences Br J Oral Maxillofac Surg 2020, Vol 58 , Issue $7,834-837$

14. Politi ,E. McParland, R. Smith, S. Crummey, K. Fan bThe impact of COVID-19 on cervicofacial infection of dental aetiology Br J Oral Maxillofac Surg (2020) $58: 1029-1033$ 